\title{
The missional impulse of the biblical narrative
}

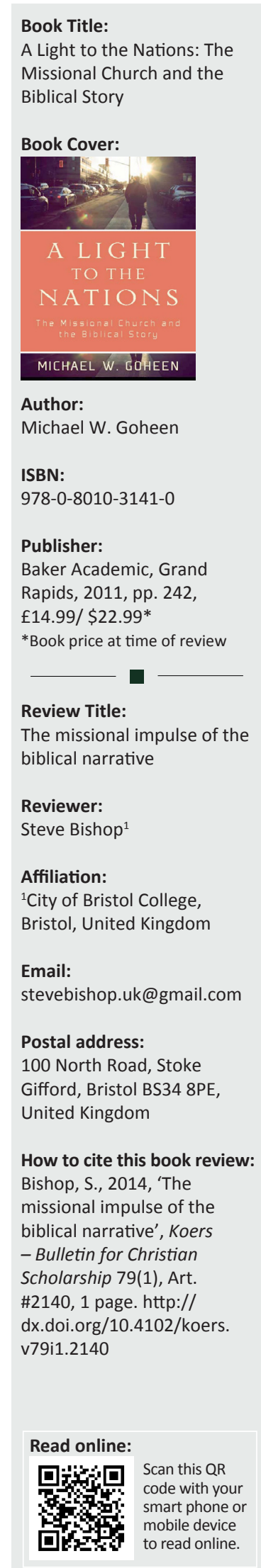

The concept of mission has too often been shaped by 19th century assumptions: mission is a matter of geography, it is a cross-cultural activity done by a select few individuals; some are called to mission, others are not. This book exposes these erroneous views and places mission in the context of Israel and the church. It provides a whistle-stop overview of 'the missional impulse in the biblical narrative'. It begins to explore the missional roots of the church in the Old and the New Testaments. Far too many missional books neglect the Old Testament; Goheen does much here to redress the imbalance.

Mission is not about doing: it is about being. The nature of being Israel, a nation called by God, was to be blessed to be a blessing. Goheen shows that there is 'much continuity between the old and new covenant peoples of God' (p. 48).

The church is to inherit the calling of Israel to be a blessing to the nations. In chapter 3 this is further explored by considering Israel's missional role among the nations. The exile and the diaspora provide an apposite model for considering the church in today's context. Assimilation and withdrawal from culture were threats just as much then as they are now. Daniel and his friends provide a role model for how we can engage; they were 'able to carry out their tasks in public life precisely because they remain rooted in a different story' (p. 65).

In chapter 4 the focus is on Jesus and his gathering of an eschatological people. Much emphasis is rightly placed on the kingdom of God. The church takes up the call upon Israel; the church becomes the renewed and restored Israel, 'the vanguard of God's end-time messianic people' (p. 86). 'The announcement of the kingdom is a message about the restoration of all human life under the rule of God' (p. 88). A sobering aspect of this call, though, is suffering. This is brilliantly developed by Goheen, drawing on Newbigin's insights. As Goheen puts it: 'A challenge to the prevailing order will bring suffering' (p. 89).

The next chapter develops the theme of the church's missional identity by looking at the death and resurrection of Jesus. Here Goheen starts by focussing on three neglected aspects of the cross: the narrative contexts, the communal and cosmic significance and its transforming power. This chapter provides an important corrective to the individualism of much contemporary evangelicalism.

One of the many strengths of this book is that, in developing the missional identity of the church, it stresses the continuity and discontinuity with Old Testament Israel. The same missionary calling is taken up by the church, but it is also to be a new eschatological community.

This book brilliantly develops the missional perspective of the body of Christ. It also takes up themes from two of Goheen's previous works (co-authored with Craig Bartholomew), The drama of scripture: Finding our place in the biblical story and Living at the crossroads: An introduction to Christian worldview, and shows why we need to live out of that scripture at the present crossroads in a missional way. The final chapter provides some practical glimpses into ways in which we can do that. Here he addresses the important 'So what?' question, but not before he has done the important ground work to be able to address that question.

This book is inspiring and insightful - it should be required reading, not only for those with an interest in missional studies, but for all those who take the lordship of Christ seriously.

A website accompanies the book: http:/ / www.missionworldview.com.

There is a two-page list of further reading, an eight-page subject index and a Scripture index comprising six pages.

\section{References}

Bartholomew G.G. \& Goheen M.W., 2004, The drama of scripture: Finding our place in the biblical story, Baker Academic, Grand Rapids. Goheen M.W. \& Bartholomew G.G., 2008, Living at the crossroads: An introduction to Christian worldview, Baker Academic, Grand Rapids.

Copyright:@ 2014. The Authors. Licensee: AOSIS OpenJournals. This work is licensed under the Creative Commons Attribution License. 